\title{
A Socio-Economic Analysis of Controls on Land Use around Hazardous Installations
}

\author{
by Philippe Rocard* and Henri Smets **
}

\section{Introduction}

The accidents in Bhopal (India) and San Juan (Mexico) highlighted the risks incurred by people who live too close to existing hazardous industrial installations. While these risks are self-evident, it is more difficult to implement controls on the use of land around such installations because of the conflicting interests involved: local politicians, industry, landowners, the public, workers, public authorities.

The French government's Inspectorate of hazardous installations is trying to ensure that decisions concerning the use of land near very hazardous installations take full account of the existence of a major accident risk. In a number of cases, projected urban developments are ill-advised because they would expose the inhabitants to industrial hazards. French public authorities can impose severe restrictions on the use of land near hazardous installations and, in this context, it would be interesting to analyse the economic ramifications of such controls.

After a brief review of the issues involved, this note will attempt to analyse the net gains and losses which result from setting out the risks involved in an existing hazardous installation and from taking account of them in decisions concerning land use. It will also consider the resulting financial impacts affecting the various parties concerned, and compare them with the so-called "probable cost" of accidents (i.e. the expected value of the cost as understood in mathematical terms). For the purpose of this note, it is assumed that the industrial facility would not affect the value of land if it were perfectly safe for the neighbourhood although, in practice, it might cause a nuisance (i.e. the negative effects such as pollution, noise, aesthetic disturbances, are offset by the positive socio-economic effects of the installation).

It should be borne in mind that assessments of situations of disaster will, by their very nature, be approximate, given that we do not know enough about the true socio-economic

* Ministry for the Environment, France.

** University of Paris I, France.

The opinions expressed in this paper are the responsibility of the authors and do not necessarily represent those of the bodies with which they are associated. 
direct and indirect impacts of such situations, or the probability of their occurrence. Furthermore, the authors are aware that the death of one or several persons cannot, and should not, be reduced to a matter of figures.

\section{How much land is concerned in France?}

Public planning controls on the use of land around hazardous industrial installations apply to installations that pose a major hazard to the public and to the environment. On the basis of current criteria (e.g. those of the EC Seveso Directive), there are about 300 such installations in France, most of them concentrated in a few major industrial regions. Such installations (e.g. chemical plants and many activities in the oil and gas sector) may cause serious damage to people nearby in the event of an explosion or a toxic gas release. Industrial installations capable of causing severe soil contamination in the event of an accident and nuclear reactors are not taken into consideration here.

A detailed survey of land use near these hazardous installations shows that the area of land around them which should not be built on - and which varies in radius from 100 to 1000 metres depending of the type of risk - totals, in France, $90 \mathrm{~km}^{2}$ after the area of the installations concerned has been deducted. However, not all activities are prohibited on such land. For example, while new housing cannot be built on it, industrial activities that do not employ a large number of workers could be authorised; it is thus possible to use the land for farming purposes as well as some well-selected non-farming purposes.

The area of $90 \mathrm{~km}^{2}$ corresponds to the total area around hazardous industrial installations in France to which land use restrictions could apply; it represents $1 / 5500$ th of the country's total land area. Over a period of 20 years, it corresponds to $4.5 \mathrm{~km}^{2}$ of land per year that cannot be developed, to be compared to an annual increase of built-up land of $145 \mathrm{~km}^{2} /$ year and an annual decrease of agricultural land of $500 \mathrm{~km}^{2} /$ year.

\section{Financial analysis}

Under present French law, owners of land on which a building ban has been imposed, unless building permission has already been granted, do not receive any compensation from the State when building permission has been refused or when the planning authorities decide that an area cannot be developed because of the risk posed by a nearby hazardous installation. However, when building permission has been refused, the various parties (local authorities, industrial firms, owners of the land, etc.) may sometimes come to an amicable agreement or find a judicial settlement in court. ${ }^{1}$

The value of a plot of land is determined to a large degree by the use to which it will be put. For example, land earmarked for commercial or urban development is likely to be worth hundred times more than farmland. A hazardous installation thus reduces the value of neighbouring land by reducing the number of uses to which it can be put.

\subsection{Losses in property values resulting from the imposition of controls on land use}

When restrictions are imposed on the use of land around hazardous installations, the owners of such land will consider that as a result they incur a large loss. Part of this reaction will be based on the mere imposition of the restrictions (loss of option) and part on an actual loss reflected in the market values of land.

\footnotetext{
1 For further information about French procedures, see "Préventique" (July/August 1989).
} 
Analysis of 40 of the above-mentioned 300 hazardous installations showed that only 25 per cent of the neighbouring land could actually be developed; the remaining 75 per cent was either already built up, formed part of an industrial estate, or could not be built up because of already imposed zoning. The difference between the value of agricultural land and that of building land around more than 30 hazardous installations was estimated. It was found to be between FF 100 and FF 350 per $\mathrm{m}^{2}$ depending on how far away the hazardous installation was, the quality of the site, whether or not the land had been developed, with an average of about FF 150 per $\mathrm{m}^{2}$. The estimate was made on the assumption that the land, subject to land-use restrictions, could only be used for farming purposes or for planting trees $\left(\mathrm{FF} 3 / \mathrm{m}^{2}\right)$. The total loss incurred by the owners of such land was estimated at about FF 3 billion using market values for the land, but owners are likely to demand more for their land.

This is approximately the cost of building a major industrial complex or a few large plants; at first sight, it does not seem much in relation to the issues at stake. By way of comparison, the French chemical industry alone spent about FF 3.6 billion per year on hazard prevention, and industry as a whole spends about FF 19 billion annually on pollution control. ${ }^{2}$

\subsection{An actual or underlying loss?}

In a perfect property market, the price of land around hazardous installations would reflect the risk of an accident, since the parties would be aware of the danger. In practice, however, potential buyers may not value such land at its true price because they are unaware of the hazards (either because they do not have full information or are denied information).

By making such risks known to the public, the government aims to ensure that land transactions take place in full knowledge of the risks involved. But as these risks existed prior to the information about them being disclosed, the loss in the value of the land is an underlying one and not ascribable to the controls imposed by the authorities. The situation is not different from that in which the owner of a piece of land discovers that the nature of the subsoil is such that foundations for the projected development cannot be laid. The land thus loses value because the nature of the ground has become known. In such cases, compensation is not warranted since they involve normal risks that every owner runs.

\subsection{Comparison of losses in the value of land around hazardous installations with the cost of a major accident such as that in Bhopal}

Such losses in land values could be compared with the cost of the compensation that has to be paid to victims when a major accident takes place. The Bhopal accident in India in 1984 resulted in the death of about 3000 people, and in permanent physical disability for about another 75000 people. The compensation for the physical damage incurred alone cost Union Carbide US $\$ 473$ million, or about FF 2.7 billion. If a similar accident with the same number of victims had occurred in France, the compensation would have been much higher. A rough estimate, based on insurance statistics for the cost of car accidents in France in 1986 , would be FF 28 billion $(3000$ fatalities $\times$ FF $350000+15000$ totally

${ }^{2}$ H. Smets: "Pollution accidentelle - L'indemnisation des tiers", Préventique, No. 32 (March/April 1989). Figures are for 1988. 
disabled $\times 1 \mathrm{MF}+60000$ partially disabled $\times \mathrm{FF} 200000) .{ }^{3}$ Obviously, however, this is only a rough estimate and should be treated with caution. From this, it is seen that the loss in the value of land created by zoning around the 300 hazardous industrial installations concerned is thus equivalent to one-tenth of the cost of the compensation that would have to be paid if just one major accident like Bhopal occurred in France.

\subsection{Cost to the country}

The effect of disclosing the risks that exist on sites near hazardous industrial installations, and of banning construction on them, is to shift the demand for building land. Dwellings that are not built in one place will be built elsewhere outside the hazardous areas. The effect of banning building on land near hazardous industrial installations may be to increase slightly the value of land available elsewhere. But if the land that is available elsewhere is less well-suited to the type of development that was originally intended, the increase in its value may not completely offset the reduction in the value of the land that cannot be built upon; in consequence, there will be a net loss resulting from the fact that the land available is less suited to the projected development. This net loss is much smaller than the loss incurred by the owners of the land near hazardous installations, or the gain accruing to the owners of land outside the hazardous area who would not have sold their land if there had not been planning restrictions on the first type of land in the first place.

Extremely close statistical observation would be required to quantify the cost to the country resulting from the fact that land outside the hazardous area is less suited to development. In the absence of such statistics, it will be assumed that this cost is equal to the cost of the infrastructure needed to develop the less suitable land. On the basis of a development cost of FF 75 per $\mathrm{m}^{2}$, and assuming that the less suitable land requires supplementary expenditures estimated at 25 per cent of this cost for the necessary infrastructure, the net loss to society of zoning is estimated at 400 million FF, i.e. much less than the loss for the owners of land.

To sum up, this zoning policy would cause on average an apparent loss of $10 \mathrm{M} \mathrm{FF}$ per hazardous site to owners of land and a net loss to society of 1.3 M FF per site. Such figures are an average for 300 sites and vary widely from site to site. Such losses are not insignificant and should be seen in the context of the risk avoided.

\section{Probabilistic analysis of planning controls on the use of land around hazardous installations}

4.1. The probability of occurrence of an accident causing 1000 off-site death in France (basic assumptions for the analysis are presented on Table 1)

To determine whether it makes economic sense to implement measures which it is certain will have financial impacts (e.g., an apparent loss of FF 3 billion to the owners of the

\footnotetext{
${ }^{3}$ On the basis of the number of victims of gas attacks during the First World War, it was estimated that the number of people who would be permanently disabled would be five times higher than the number of deaths. In 1915-1918 gas attacks (chlorine, phosgene and mustard gas) caused 27827 dead and 149400 injured (see R. Andurand, "Elément de sûreté chimique et de désastrologie", 1989, p. 33). Elsewhere in this paper we have used a ratio of five totally-disabled people to every one death, and of four partially-disabled people to one totally-disabled person. Strictly speaking, this assumption is probably not valid for a gas explosion such as that which occurred in San Juan (Mexico), which caused relatively few disabled victims.
} 
land that cannot be developed), as compared with the higher expense that would result from an event that is uncertain, it is necessary to quantify the probability of that very rare event occurring. To be on the safe side in our analysis, we will seek a lower estimate. Unfortunately, information is lacking for providing a range of values of this estimate.

Table 1:

\section{Basic assumptions}

1) Accident Type: 1000 deaths 5000 victims completely disabled 20000 victims partially disabled

2) Accident rate: $\quad 0.3$ acc. per 1000 years

3) Societal aversion factor for disasters (1000 deaths): 300

4) Value of a death: $\quad 0.35 \mathrm{MF}$ for insurance $20 \mathrm{MF}$ to individual $5 \times 300=1500 \mathrm{MF}$ to society

5) Land value: $\quad 1 / 4 \times 90 \mathrm{~km}^{2} \times 150 \mathrm{~F} / \mathrm{m}^{2}=$ $3000 \mathrm{MF}$ loss to landowners $1 / 4 \times 90 \mathrm{~km}^{2} \times 1 / 4 \times 75 \mathrm{~F} / \mathrm{m}^{2}=$ $400 \mathrm{MF}$ net loss to society

Analysis of accident statistics in France suggests that an industrial accident causing 10 deaths occurs once or twice every 10 years. On the basis of the Pareto statistical distribution (see Insert No. 1), the probability of occurrence of an accident giving rise to 100 deaths is once every 100 years, and that of an accident causing 1000 deaths is once every 1000 years. Figure 1 provides some support to this extrapolation. ${ }^{4}$

\section{Insert No. 1 \\ Pareto distribution}

According to the Pareto distribution (index 1), the number of accidents of a size greater than $x$ is an inverse function of $x$ for high values of $x$. For example, if there are 100 accidents involving 1 or more deaths, there will be 10 accidents with 10 or more deaths, and 1 accident with 100 or more deaths. When Pareto's law is satisfied, the aggregate gravity of accidents in successive classes of gravity is constant. Thus, the total number of deaths in accidents involving 1 to 9 deaths is the same as the total number of deaths in accidents involving 10 to

\footnotetext{
4 The probability of occurrence of a rare event can also be estimated using quantitative risk analysis specific to each hazardous installation; this makes it possible to calculate the risk of death incurred by people living near such installations, and particularly on land on which there is a ban on housing development.
} 
99 deaths. The Pareto distribution is usually observed in the statistical description of major technological accidents such as mining, dam and transport accidents, and those involving chemical or petroleum plants (see figure 1). It also holds for fires and oil spills. The hypothesis that the probability of occurrence in France of an accident involving 1000 or more deaths is $10^{-3}$ /year is equivalent to the hypothesis that the probability of occurence of an accident involving 10 or more deaths is once every ten years, or that of an accident causing 5 or more deaths is once every 5 years.

Over the period 1980-1989, the following accidents involving four or more deaths occurred in France in fixed hazardous installations:

Richemont-Hayange, 1982: rupture of gas pipeline by pusher boat, 5 deaths.

Metz, 1982: explosion in malt house silos, 12 deaths and several injured.

Montreuil, 1983: release of hydrocyanic acid, 4 deaths.

Issoire, 1986: explosion of 3 aluminium smelting furnaces, 4 deaths.

Ablon, 1988: explosion in a dynamite works, 5 deaths and 5 injured.

Boussens, 1989: hydrogen leak and explosion, 4 deaths and 3 injured.

The occurrence of these six accidents over a period of 10 years is consistent with the hypothesis of 2 accidents causing at least 8 deaths and less than 16 deaths every 10 years. For the sake of simplicity, we have adopted the lower hypothesis of 1 accident with 10 or more deaths on site once every 10 years. By extrapolation, the probability for an accident involving 1000 or more deaths is $10^{-3} /$ year in France. This estimate is consistent with the available data, but it entails a sizeable margin of uncertainty. Accidents involving 1000 or more deaths off-site are much less frequent.

Given that very serious accidents usually occur less frequently than the values extrapolated from the Pareto distribution, it seems appropriate to consider that the probability of an accident causing 1000 deaths in France is less than $0.510^{-3} /$ year. This corresponds to a maximum probability of $1.710^{-6}$ /year per installation if there are 300 installations in France in which an accident involving 1000 deaths could occur. It will be noted that this probability is about the same as the estimated probability of a major nuclear accident in France (between 1 and 5 10-5/year for a contained meltdown, and probably ten times less for a meltdown in which the confinement is ruptured). ${ }^{5}$

This estimate is comparable with the statistics available at European level from which it can be shown that the probability of an accident causing 1000 deaths in France is about $0.710^{-3} /$ year. $^{6} \mathrm{~A}$ third approach is based on the observation that the last industrial acci-

${ }^{5}$ See the studies by Electricité de France (EDF) and the Institut de Protection et de Sûreté Nucléaire (IPSN) on the probability of a melt-down of a nuclear reactor (Le Monde, 25/5/90).

${ }^{6}$ According to data from FACTS accident data bank (TNO, the Netherlands) which were analysed by the OECD, over the period 1974-1985, there were 10 accidents each involving more than 11 deaths in hazardous installations, i.e. an average of 0.8 per year. On the basis of one accident involving 10 deaths or more per year in the 24 OECD countries, and of an accident distribution proportional to GNP, France would have $0.710^{-1}$ accidents involving more than 10 deaths per year. Extrapolating from the Pareto law, we get $0.7 \quad 10^{-3}$ accidents involving more than 1000 deaths per year in France. Estimates of the risks attached to propane and ammonia in France give a risk of $10^{-5} /$ per year for an accident involving 1000 deaths. This is about the same as the risk arising from the transport of hazardous substances in the Lyons region (see the study by P. Hubert, CEPN Report No. 159). 
dent in Western Europe that caused 500 deaths occurred 70 years ago (561 deaths in 1921 in Oppau, Germany). Assuming that accidents are distributed across countries in proportion to their GNP, the probability of occurrence in France of an accident causing 500 deaths is about 16 per cent of $1 / 70$, i.e. $2.210^{-3} /$ year, and, for an accident causing 1000 deaths, $1.110^{-3} /$ year.

\section{Figure 1:}

\section{Accidents}

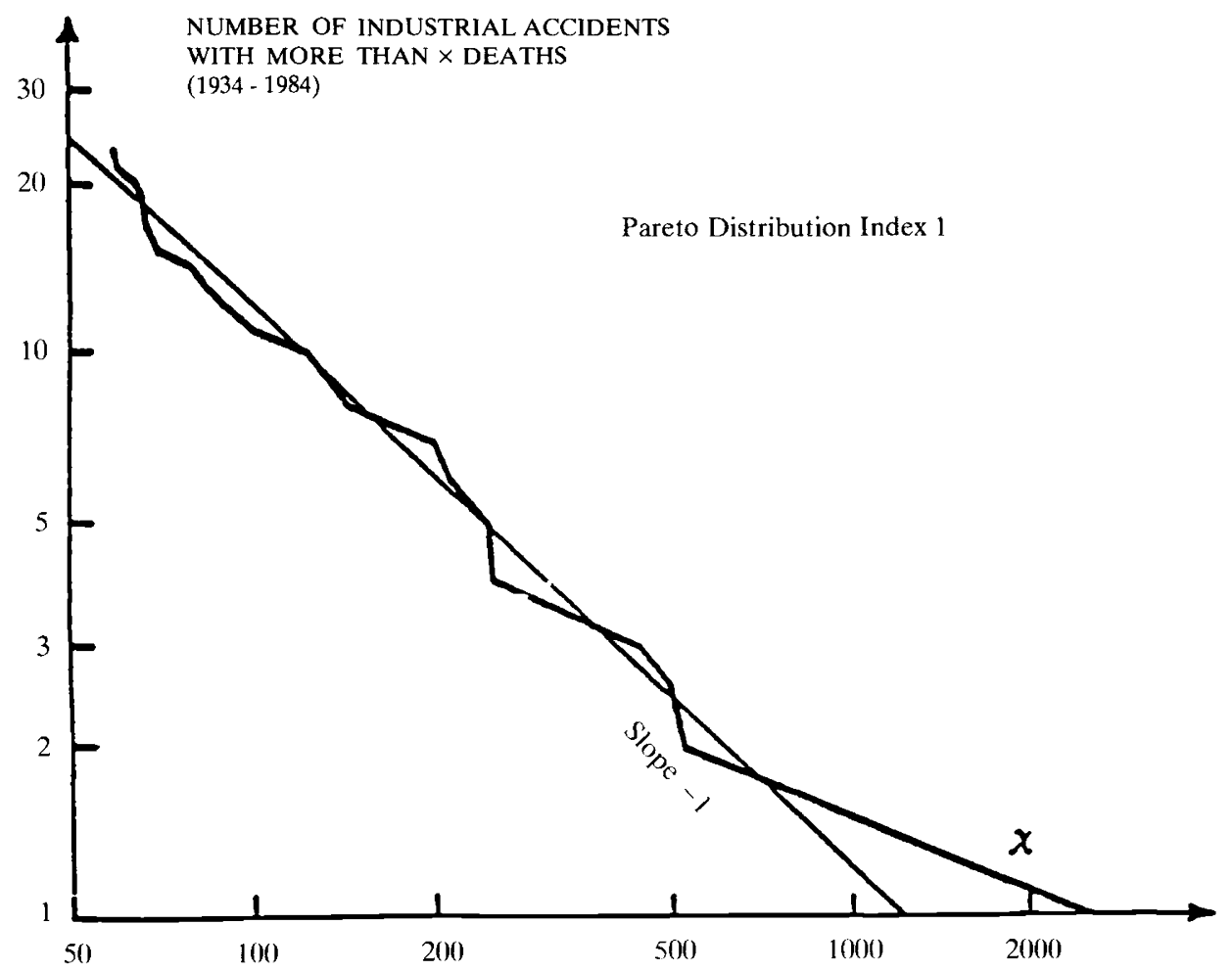

Number of deaths 
Finally, in the past 15 years there have been 7 accidents in hazardous installations in the world, each involving more than 100 deaths. ${ }^{7}$ As France's GNP is 4.3 per cent of world GNP, the probability of occurrence of an accident causing 100 deaths or more is approximately equal to:

$$
\frac{7}{15} \times \frac{4.3}{100}=20.10^{-3}
$$

i.e. $2 \cdot 10^{-3} /$ year for an accident causing 1000 deaths or over. On the basis of these various approaches, we adopted a fairly small disaster rate of $0.510^{-3} /$ year because of the relatively greater safety of French installations than those in many developing countries.

Assuming that the probability of occurrence of an accident causing 1000 deaths in France is $0.510^{-3} /$ year, the probability of occurrence of an accident causing 1000 off-site deaths is obviously less. Although the deaths resulting from the accidents in San Juan (Mexico) and Bhopal (India) were virtually all off-site, it will be assumed that there is one on-site death for every two off-site deaths in the event of a serious accident. On the basis of this approach, the probability of an accident causing 1000 off-site deaths in France might be in the order of $0.310^{-3}$ per year. ${ }^{8}$ Such a figure is a mere extrapolation which clearly entails a wide margin of uncertainty.

${ }^{7}$ Since 1975 , there have been the following accidents in fixed installations, each involving more than 100 deaths.:

Chasnala, India, 1975 : Factory, 431 deaths (?).

Novosibirsk, USSR, 1979: Chemical plant, 300 deaths (?).

Danociabasi, Turkey, 1980: Butane gas explosion, 107 deaths.

Tacoa, Venezuela, 1982: Hydrocarbons storage tank explosion, 145 deaths.

Cubatao, Brazil, 1984: Petrol pipeline explosion, 508 deaths.

San Juan, Mexico, 1984: LPG tank explosion, 503 deaths.

Bhopal, India, 1984: Pesticide plant, 2800 deaths.

Romania, 1984: Chemical plant explosion, 100 deaths (?).

Islamabad, Pakistan, 1988: Explosion of a munitions depot, over 100 deaths.

Acha Ufa, USSR, 1989: Gas pipeline explosion, more than 575 deaths and 623 injured.

If pipeline accidents and those involving munitions are eliminated, in 15 years, there have been at most 7 accidents each involving more than 100 deaths, i.e. 0.5 accidents with 100 deaths or more per year worldwide.

8 This level of risk of $0.310^{-3} /$ year for an accident with 1000 deaths off-site in France $\left(10^{-6 /} /\right.$ year per hazardous installation on the basis of 300 installations) is comparable with the levels considered acceptable in the United Kingdom:

$-10^{-5} /$ year for an accident with 100 deaths caused by a nuclear reactor (i.e. less than $10^{-4} /$ year per reactor);

- $0.210^{-3} /$ year for the Canvey Island industrial complex (1500 deaths), which comprises several hazardous installations.

(See Health and Safety Executive (HSE)): "The tolerability of risk from nuclear power stations", London, 1987). This value is extrapolated from a risk of an accident causing 10 deaths of $10^{-1} /$ year, i.e. $310^{-4} /$ year per installation. In the Netherlands, the target is to limit the risk of an accident involving 10 deaths off-site to a maximum of $10^{-5} /$ year per installation. It should be noted that the assumed probability for an accident with 1000 deaths off site in France (10-6/year per installation) is a thousand times higher than the target value in the Netherlands $\left(10^{-9}\right.$ per year per installation). This discrepancy is related to the inclusion of a disaster aversion factor of 1000 in the Netherlands. 


\subsection{Economic analysis from the standpoint of the compensation that would be paid by in- surers in the event of an accident}

The compensation that would actually be paid in France for an accident causing 1000 deaths is likely to be $1000 \times 0.35 \mathrm{FF}$ million $=\mathrm{FF} 350$ million when using statistical data for road accidents. If to this one adds 5000 completely disabled victims and 20000 partially disabled victims, the compensation might reach FF 10 billion.

If such an event occurred with a frequency of $0.310^{-3} /$ year, the "probable" cost (mathematical expectation) of the risk would be $0.3 \times \mathrm{FF} 10 \mathrm{million} / \mathrm{year}=\mathrm{FF} 3 \mathrm{million} /$ year. It is clear that it would not make economic sense to prohibit building on land around hazardous installations, at a cost of FF 3 billion to landowners or FF 400 million to society, merely to avoid the risk of such a small amount of compensation to be paid. This conclusion would also hold if the probability of a major accident was much higher.

\subsection{Economic analysis from the standpoint of potential victims (Table 2)}

However, analysis in terms of the compensation that would be paid to victims in the event of an accident is biased by virtue of the fact that courts place a much lower value on life after an accident than potential victims would before an accident ${ }^{9}$ If a life is valued at FF 20 million, a value which reflects the implicit value of life rather than some value decided by public authorities. ${ }^{10}$ (See Insert No. 2), the cost of an accident causing 1000 deaths would be FF 20 million $\times 1000=$ FF 20000 million. If we add 5000 completely disabled people whose disability is valued at FF 10 million, and 20000 partially-disabled people whose disability is valued at FF 2 million, the total social cost of the accident is FF 110 billion. Assuming a rate of occurrence of major accidents of $0.310^{-3} /$ year, the "probable" cost of an accident would be $F F 33$ million/year.

9 The value actually paid after a fatal accident to the family of the deceased is usually smaller than the value of a statistical death before an accident for the society (calculated by the willingness to pay in relation to a small decrease in fatal risk). Part of the reason is that the deceased is not compensated for the loss of his life and that society is not compensated for the loss of investment and returns resulting from an early death.

${ }^{10}$ The value of an avoided death varies according to the nature of the risk (whether the risk is accepted freely or whether it is imposed), the frequency of the risk and the type of activity involved (small or large firms, private transport of chemicals, etc.). Recent studies of the implicit value of an avoided death for imposed small risks give values of about FF 20 million (1990); this corresponds to the amount that a potential victim is willing to pay to avoid the risk of death. Thus, in 21 studies of revealed preferences, $M$. W. Jones-Lee collected statistical values of life and obtained an average of $£$ 1.9 million at 1989 prices). Twelve questionnaires-based studies gave an estimated average statistical value of life of $£ 2.9$ million at 1989 prices, and a median value of $£ 1.8$ million. All the data available suggest that a value of FF 20 million per death avoided is reasonable from the standpoint of the person exposed to the risk. For implicit value of an avoided death, see:

- G. BLOMQUIST: "Estimating the value of life and safety, recent development" in "The value of life and safety", M. W. Jones Lee (Ed.), North Holland, 1981.

- "Environmental Policy Benefits : Monetary Valuation", OECD, Paris, 1989 (p. 37).

- M. W. JONES-LEE: "The value of transport safety”, Oxford Review Econ. Policy 6, 39 (1990).

- J. LOMBARD, P. HUBERT, P. PAGES: “L'intégration du risque lié au transport et au stockage des produits chimiques dans la planification urbaine. L'apport des outils d'analyse décisionnelle", CEPN No. 163 (1989). 
Insert No. 2

\section{Various values for a death}

\section{A. Actual death}

FF 0.23 million : ${ }^{1} \quad$ Average compensation paid in 1988 by French insurance companies for a death during a road accident.

FF 0.35 million : ${ }^{1}$ Average compensation paid in 1987 by French insurance companies for the death of a male during a road accident.

B. Death avoided (values used in public investment decisions)

FF 1.8 million: ${ }^{2} \quad$ Value of an avoided death in 1990 (FF 1.6 million in 1986) used by the French public authorities in calculations related to the safety of road infrastructures (this value is based on the so-called "human capital" method, i.e. on the output or income loss resulting from a death).

FF 5 million: ${ }^{3} \quad$ Value of an avoided death used by the UK highways authorities and the UK Health and Safety Executive (1987).

FF 7 million: ${ }^{3} \quad$ Value of an avoided death used by the Swedish highways authorities (1989).

FF 8 million : ${ }^{4} \quad$ Value of an avoided death used by the US Department of Trans(\$1-2 million) port.

FF 20 million: $5 \quad$ Value of an avoided death used by the US Environmental Protection Agency (1990). (\$1.6-8.5 million, 1986).

C. Deaths avoided (values placed by individuals on avoidance of a fatal risk, i.e. a reduction in the probability of death).

FF 20 million: ${ }^{6} \quad$ Value of an avoided death (calculated by the revealed preferences or willingness-to-pay method) (1989).

FF 94 million: ${ }^{6} \quad$ Value of an avoided death for workers in nuclear power stations (1990 FF).

FF 700 million: ${ }^{6} \quad$ Value of a death avoided in the community near nuclear power stations (1990 FF).

Sources:

1 AGSAA Statistics (road insurance), 1986.

2 CETU and Services d'Etudes Technique des Routes et Autoroutes (SETRA), 1986 (see note 10).

${ }^{3}$ M. W. Jones-Lee: "The value of transport safety", Oxford Review Econ. Pol., 6, 39 (1990).

4 OECD, Public Management Service, July 1990, personal communication.

5 See note 17 p. 484.

${ }^{6}$ See notes 10 and 12 . 
Table 2:

Cost benefit analysis for France

Probable avoided Real cost

damage (certain)

For society

Cost of a disaster

$6600 \mathrm{MF}$

$450 \mathrm{MF} /$ year

Net cost to society of a construction ban

$400 \mathrm{MF}$ i. e.

$27 \mathrm{MF} /$ year

For individuals

Damage cost as viewed

Cost to landowners by potential victims $33 \mathrm{MF} /$ year of a construction ban $3000 \mathrm{MF}$ i.e. $205 \mathrm{MF} /$ year

N. B. The probable value of avoided damage for the liable party (and his insurer) is $3 \mathrm{MF} /$ year (10 $000 \mathrm{MF}$ per acc.)

Viewed in this light, the prohibition of building on land around hazardous installations, at a net cost of FF 400 million to society, would be justified if it made it possible to avoid a disaster taking place during a period of over 30 years, i. e.during the life expectancy of existing industrial installations. If the accident rate was higher, this conclusion would be strengthened.

However, this kind of analysis is based only on the financial impact of a disaster on local residents, whereas in practice it would affect all society with far-reaching political repercussions.

\subsection{Economic analysis from the standpoint of the political and social impact of an industrial disaster (Table 2)}

Restrictions on building on land near hazardous installations also need to be viewed within the broader context of the society that implement them, and in the light of the relative importance that society attaches to severe accidents. It makes sense for society to ban development on land around hazardous installations if the social cost of a disaster is greater than the cost of the ban for avoiding such a disaster.

The social or political cost of a disaster to society can be calculated by multiplying the social cost of the deaths by a so-called disaster aversion factor. The social cost of a death can be estimated at FF 5 million; this is the figure used by the UK and Swedish public authorities (Insert No. 2) when valuing a death in road construction decisions; it is higher 
than the figure currently used in France ${ }^{11}$ but less than what French industry spends on avoiding the death of a worker (between FF 6 million and FF 94 million). ${ }^{12}$

The disaster aversion factor is the factor by which the social cost of many deaths that occurs individually $(1000 \times$ FF 5 million $)$ needs to be multiplied to calculate the social or political costs of many deaths occurring simultaneously. It reflects the fact that 1000 deaths occurring simultaneously in a disaster in the chemical industry have a much greater impact on French society than 1000 deaths occurring individually in road accidents.

\section{Insert No. 3 \\ Disaster aversion factor}

The cost of a major accident to society includes many indirect costs which would have been avoided or would have occurred much later if the accident had not taken place. Since production is halted in an installation in which an accident has taken place, it is necessary to produce the output elsewhere, with resulting extra costs. When an accident occurs in an installation, it is sometimes necessary to shut down other similar installations in order to carry out checks and repairs. In the longer term, new regulations are introduced because of the increased anxiety about the safety of existing technologies, checks become more stringent and existing installations are improved. Old technologies are gradually replaced by new ones that are considered to be less hazardous. In the end, when a major accident

11 A report by the OECD - "Methods for evaluating road safety measures" (1981) - estimated the cost of a road fatality in 1976 to be $\$ 213425$ in Germany, $\$ 145574$ in Sweden and $\$ 140900$ in France. This would be compatible with a cost of FF 2 million in 1990. Studies by LE NET ("Le Prix de la Vie Humaine", La Documentation Française, Paris, 1980) and DUVAL (Insécurité routière, le coût socioéconomique des dommages corporels, INRETS, Paris, 1986), estimate the social cost of a road fatality to be between FF 1.5 and FF 2 million (15 times average annual income), basing their estimate on the output losses resulting from the fatality. The OECD Report - The Social Cost of Land Transport (Environment Monograph No. 32, 1990) - estimated the cost of a road fatality to be FF 3.4 million (1985) in Germany, FF 2.6 million (1986) in the United Kingdom and FF 2 million (1985) in France. The instructions from the French Ministry of Town Planning, Housing and Transport (CETU and SETRA notes in 1986) indicate a cost of FF 1.6 million per fatality. However, this figure is for risks incurred voluntarily, and thus cannot be transposed directly to risks in the chemical industry. Furthermore, it is not an estimate of willingness to pay. If one takes into account the total cost of fatalities to the government (police, justice, health, public facilities, etc.) and the cost of insurance companies, the cost of a fatality would be closer to the figure of FF 5 million used in this report and in the United Kingdom.

12 Investment in safety measures (expenditures on saving one statistical life) varies widely from one type of activity to another. According to a survey by J.-P. Moatti and J. Lochard (see the study published in "La Socié té Vulnérable", Presses de l'Ecole Normale Supérieure, Paris, 1988), the implicit cost of avoiding the death of a worker in the asbestos industry, i.e. of ensuring compliance with safety standards, is FF 4 million per fatality avoided at 1981 prices (or FF 6.4 million at 1990 prices), FF 7 million per fatality at 1987 prices for hospital workers exposed to the risk of irradiation, and FF 59 million per fatality at 1981 prices (or FF 94 million at 1990 prices) for workers exposed to radiation risk in nuclear power stations. The implicit cost of avoiding a fatality among the local community is much higher (e.g. 8 times or more or FF 490 million per fatality at 1982 prices for nuclear power stations). The implicit cost of avoiding the risk posed to the public by vinyl chloride is FF 6 million per fatality at 1983 prices for investment in old plants, and can rise to FF 2640 million per fatality at 1983 prices for investment in new plants. An implicit cost of at least FF 20 milion per fatality avoided among people who live near existing chemical plants would seem likely. Independently of these estimates, in a study published in "La Société Vulnérable", H. Bohnenblust estimates the willingness to pay to avoid an accident in industry to be around FF 12 million per fatality. In the specific case of the risk posed to the public by the transport of explosives, he estimates a willingness-to-pay to avoid an accident of FF 40 million per death avoided. 
takes place, the entire industrial sector must bear costs that are much greater than those incurred by the installation in which the accident has taken place. Furthermore, society has to bear the costs of damage that is not compensated for (general effects on health, the climate, the economy, agriculture. etc.) and of changes in demand resulting from the accident. Society has to take account of the direct costs, the indirect costs and the induced effects of an accident. The aversion factor is a sort of rough measure of the presumed size of the indirect effects of an accident compared with its direct effects. It expresses the proportionally greater importance attached by decision-makers to major accidents as compared with "ordinary" accidents. Surveys carried out among decision-makers show that the aversion factor increases, amongst others, with the seriousness of the accident.

Recent studies have shown that the aversion factor for a disaster causing 1000 deaths is well over 30 , and could be as high as 1000 . The official practice in the Netherlands on socially acceptable industrial hazards are compatible with the latter figure (Insert No. 3). On the basis of the studies by Bohnenblust in Switzerland and Germany ${ }^{13}$ and by Hubert in France, ${ }^{14}$ we used an aversion factor of 300 . Thus the social or political cost of an industrial disaster causing 1000 deaths would be FF 5 million $\times 1000 \times 300=$ FF 1500 billion. This figure is very high even in comparison to GNP (FF 5500 billion/year); in fact, however, it reflects a political and social valuation of the significance of the risk of a disaster rather than an actual or a potential financial transfer.

To assess the social or political utility of spending FF 3 billion on compensating the owners of land on which there is a building ban, it is necessary to calculate the discounted probable cost of the damage avoided as a result of the ban (see Insert No. 4). On the basis of a 6 per cent discounting rate and a 30 years period, the discounted probable cost would be 14.6 times the probable cost in one year. Given that the probability of an accident with 1000 off-site deaths occurring in France was estimated to be $0.310^{-3} /$ year, the discounted probable cost would be $14.6 \times 0.3 \times \mathrm{FF} 1500$ million $=F F 6.6$ billion.

It is seen that the discounted probable cost of the disaster is greater than the loss to the owners of the land on which building is banned ( 3 billion FF). From the social or political standpoint therefore, it makes sense to ban building on such land even if it means that the owners have to be compensated. This conclusion would be strengthened if there was a higher probability of accident, a lower discount rate, or a higher value of life.

13 According to a study by A. Bientz and H. Bohnenblust ("L'évaluation du risque comme outil de gestion économique", published in "La Société Vulnérable", Presses de l'Ecole Normale Supérieure, Paris, 1988), the marginal costs of avoiding a fatality need to be multiplied by a factor of about 20 , depending on whether the accident occurs on the roads or in a factory. Furthermore, there is a risk aversion factor of 16 depending on whether the accident causes few or many victims. The product of the two factors gives a chemical disaster aversion factor of 320 .

14 According to studies carried out by $\mathrm{Ph}$. Hubert et al. in the Lyons region (Ph. Hubert, M. H. Barny and J. P. Moatti: "Elicitation of decision-makers' preferences for management of major hazards", Risk Analysis, Vol. 11, No. 2, 1991), French decision-makers' propensity to pay to save a life in a road disaster involving the transport of hazardous substances is about 50 to 100 times higher than their propensity to pay to save a life in an ordinary road accident. These findings are consistent with the hypothesis that the aversion factor for an accident involving $\mathrm{N}$ deaths varies proportionately to the power $2 / 3$ of $\mathrm{N}$ ( and not to $\mathrm{N}$ as can be derived from the Dutch policy). According to Hubert's studies, the aversion factor for an accident involving 1000 deaths is 300 when compared to an accident involving 10 deaths and the value of one death in a disaster is FF $500 \mathrm{M}$. 


\section{Insert No. 4 \\ Present value of future damage}

The present value of damage $\mathrm{C}$ occurring every year is obtained by weighting each type of damage by a discounting factor; the later the damage appears, the lower the discounting factor. The discounting factor is $1 /(1+r)^{n}$ where $r$ is the discounting rate and $n$ the year in which the damage occurs. The present value of damage occurring during $N$ successive years is given by:

$$
\sum_{0}^{N} C /(1+r)^{n}
$$

The discounting rate is often taken to be equal to the difference between the long-term interest rate and the average rate of inflation. However, the authorities frequently use higher discounting rates (of about 7 per cent in real terms) because they want to give more weight to short-term than to long-term effects. However, a sustainable development policy in the area of environment cannot be based on high discounting rates.

$$
\text { DISCOUNTING FACTOR: } \sum_{n=o}^{N} \frac{1}{(1+r)^{n}}
$$

\begin{tabular}{lrrrr}
\hline \multicolumn{1}{c}{$N$} & 15 & 30 & 50 & $\infty$ \\
$r$ & & & & \\
\hline 3 & 12.3 & 20.2 & 26.5 & 34.3 \\
4.5 & 11.2 & 17.0 & 20.7 & 23.2 \\
6 & 10.3 & 14.6 & 16.7 & 17.7 \\
7.5 & 9.5 & 12.7 & 13.9 & 14.9 \\
9 & 8.8 & 11.2 & 11.9 & 12.1 \\
\hline
\end{tabular}

N.B. $\quad \sum_{0}^{\text {oo }} \frac{1}{(1+r)^{n}}=\frac{1+r}{r}$

This analysis could be refined by taking into account accidents involving 100 deaths, major damage involving cases of total or partial disability; this would increase considerably the social cost of not having building controls on land around hazardous installations. But we shall not refine the analysis any further, since the conclusion would be the same: it is preferable for society to prevent an accident that would cause 1000 deaths off-site even if this means spending FF 3 billion to compensate the landowners. 
4.5. Economic analysis from the standpoint of the repercussions of an accident on industry as a whole (Table 3)

A ban on building houses near hazardous installations can be seen as a form of "insurance" for the industries most directly concerned and for industry as a whole because it means that they are less likely to have to meet costly regulatory requirements that might be introduced to reduce the frequency and impact of major accidents on nearby housing.

Table 3:

Overall comparisons

Construction ban :

Cost of compensating all landowners:

$3000 \mathrm{MF}$

No construction ban but more safety:

$10 \%$ additional expenses on safety expenses in

chemical industry during 30 years

$5260 \mathrm{MF}$

or

$0.5 \%$ additional investment for 30 years

$7300 \mathrm{MF}$

Probable cost of a disaster:

$6600 \mathrm{MF}$

The overall consequences of a major accident on industrial activity as a whole depend a lot on the way society reacts to it. If the reaction is strong, the cost of a single serious accident could be much larger than the effects on the neighbourhood. A possible breakdown of the costs is as follows:

Direct effects of an accident in the neighbourhood:

- FF 10 billion on compensation to be paid to the victims (see point 3.2.) near the installation where the accident took place;

Induced effects of an accident in the country:

- FF 80 billion for closing down and moving industrial installations that are too near dwellings;

- FF 25 billion for a 25 per cent increase in safety spending in the chemical industry over 30 years;

- FF 15 billion for an increase in safety spending in other industrial sectors over 30 years in France.

Instead of 10 billion francs, the accident would cost 130 billion francs to industry. The discounted probable value of the total cost of a disaster possibly occurring in the future is equal to $130 \times 0.310^{-3} \times 14.6=$ FF 570 million, i.e., more than the net loss to society of a construction ban. 
In addition to this "probabilistic" cost, it is necessary to take into account a cost that could be avoided. If there is a ban on building on land near hazardous installations, and if, as a result, no disaster takes place, it would be possible to dispense with additional safety measures which, even if they did not require a completely new technology in the installation in question, would nonetheless require that considerable modifications be made to it. Assuming that the additional cost thus avoided by industry ${ }^{15}$ is equivalent to 10 per cent of current expenditure on safety in the chemical sector alone, the present value of the extra cost avoided over 30 years would be $0.1 \times$ FF 3600 million $\times 14.6=$ FF 5260 million. Such cost would be avoided if there was a construction ban.

Another approach to this estimate is that, if there were no planning controls on the use of land near hazardous installations, pressure from society and local residents would oblige industry gradually to invest in new safety requirements over a period of 30 years. If such investments represent an annual cost of only 0.5 per cent of total investment already made in hazardous installations, i.e. FF 0.5 billion a year, the total discounted cost of these new safety investments would be FF 7.3 billion. This cost could be avoided by banning building on the land around hazardous installations.

From every point of view therefore, it is obvious that the cost that is avoided by industry by having a ban on building is much higher than the loss incurred by the owners of the land around hazardous installations, and that in consequence a ban on building could be financially advantageous to the industry as a whole, even if the cost of the compensation of the owners of the land had to be borne by the industry (Table 3).

\section{Conclusions}

The need for planning controls on the use of land around hazardous installations is demonstrated by the fact that serious accidents continue to occur. ${ }^{16}$ The land use measures implemented in France are not particularly costly when compared with the size of the risks that they are designed to avert.

From the point of view of the community at large, a ban on building on land near an hazardous installation results in only a small net financial loss to society while making it possible to limit the possible consequences of a major accident. This financial loss is estimated at FF 400 million in France taking account of the gains and losses in land values resulting from the restrictions imposed. But compared with the damage that would be avoided if a major accident took place, these measures make economic sense.

15 This approach means that industry has not taken all possible measures to prevent accidents occurring and was spared from taking certain measures which would only be justified in order to avoid a very improbable disaster.

${ }^{16}$ Although major accidents are rare, they nonetheless continue to occur. For example, in 1989, in the Soviet Union a storage tank burst suddenly, releasing 7000 tonnes of ammonia. A tanker carrying 23000 tonnes of methane exploded off Japan and sank. In the Soviet Union a gas pipeline leak caused a fireball 600 metres of diametre and an explosion equivalent to 2500 tonnes of TNT; another leak in the pipeline produced a similar fireball. In Pakistan an ammonia cloud intoxicated between 1000 and 1500 people. In the United States, a polypropylene plant exploded (causing over $\$ 750$ million worth of material damage, 23 workers killed and 124 injured), while a gas explosion in a refinery caused damage over a radius of 10 kilometres. Notwithstanding, all the safety measures taken, a major industrial accident in France cannot thus be ruled out entirely. 
The apparent loss incurred by the owners of the land on which building is prohibited is much larger - an estimated FF 3 billion. This loss is much larger than the probable amount of direct compensation that would be paid to victims of an accident, or the probabilistic value of the risk perceived by the people exposed to it. However, it is much smaller than the social or political cost of a major accident or the probable expenditure that a building ban would allow industry to avoid. This discrepancy can be explained by the fact that society has a marked aversion to major accidents, and takes special measures to prevent them or to prevent them from recurring.

To sum up, it is seen shown that planning controls are clearly warranted at country level by the need to prevent situations in which major accidents can occur; such accidents are socially unacceptable and pose a risk whose direct and indirect financial consequences would, overall, be more costly for industry. A ban on building on land near hazardous installations would make economic sense to society and to industry even when the owners of the land near the hazardous installation are fully compensated.

17 See Insert No. 2 page 477 . According to the study by D. M. Violette, L. G. Chestnut and A. Fischer - "Valuing Risks: New Information on Paying for Changes in Fatal Risks", Toxics Law Reporter, pp. 349-357 (September 1986) - the value of a human life as measured by the bonuses paid to workers who are exposed to a risk, is between $\$ 1.5$ and $\$ 3$ million at 1984 prices for occupational risks that have been incurred of the worker's own free will. The studies by Travis et al. - "Cancer Risk Management", Env. Sci. Techn. 21, 415 (1987) and also "Cost Effectiveness as a Factor in Cancer Risks Management", Env. Int. 13, pp. 469-474 (1987) show that in the United States, if the risk of a chemical accident is slight, it is not regulated if the cost of doing so exceeds $\$ 2$ million at 1983 prices per fatality avoided. This "going rate" is in line with the suggestion by the US Environmental Protection Agency (USEPA) that regulation is justified if the cost per life saved is less than $\$ 1.5$ million (see "Guidelines for Performing Regulation Impact Analysis", EPA 230/01-84-0003, EPA, 1983). In 1983, the Nuclear Regulatory Commission set as an objective a cost of $\$ 1000$ per man rem avoided for the nuclear industry (NUREG 0880, Rev. 1), i. e. \$3.6 million per life saved. Morall's studies of the cost of federal regulations give an average cost of $\$ 3.6$ million (Regulation, Nov.-Dec. 1986).

A more recent study by Ann Fisher (Ann Fisher et al.: "The Values of Reducing Risks of Deaths: a Note on New Evidence", Journal of Policy Analysis and Management 8, 88-100 (1989) concluded that for individual risks of a probability of $10^{-4} /$ year, the value of a life would be between $\$ 1.6$ and $\$ 8.5$ million at 1986 prices, for risks incurred voluntarily. All the available data suggest that the value of an avoided death is more than $\$ 3$ million at 1984 prices for imposed risks, i. e. $\$ 3.9$ million at 1990 prices or FF 20.5 million prices $(\$ 1=\mathrm{FF} 5.26)$. However, this figure corresponds to risks incurred voluntarily: in the case of exposure to risks from living near a chemical plant, the value of an avoided death of a local resident would very probably be much higher. According to Ivy E. Broder, a serious industrial accident which is known to the public entails a loss for the shareholders which is as high as $\$ 50$ million per death for a period of 20 days after the accident. This figure is much higher than the social value of an avoided death ( $\$ 5$ to 6 million according to Broder) or to the compensation awarded by American juries (approximately $\$ 1$ million per death in 1985) (see "The Cost of Accidental Death: A Capital Market Approach", J. Risk Uncertainty 3, 51-63 (1990). 